\title{
EFFECT OF SUPERPLASTICZER ON SILICA FUME POZZOLANIC CEMENT
}

\author{
Magdy A. Abd El.Aziz \\ Associate Prof. of Structural Eng., Faculty of Eng., Fayoum University
}

(Received January 6, 2010 Accepted June 2, 2010)

Silica fume is a by-product in the production of silicon or its alloys. It is very fine material and has a surface area $=20 \mathrm{~m}^{2} / \mathrm{gm}$. It is a siliceous material and contains (85-95) \% $\mathrm{SiO}_{2}$ in an amorphous state. It reacts with lime in the presence of moisture at normal temperature to form calcium silicate.

The aim of the present work is to study the effect of silica fume substitution on the characteristics of ordinary Portland cement. Different mixes of OPC and various proportions of silica fume with and without superplasticizer were prepared in tap water and hydrated up to 90 days. The hydration behavior was followed by measuring the free lime and porosity. Also, the physico-mechanical properties of each mix were measured such as water of consistency, setting times compressive and splitting strengths. The results have shown that, the water of consistency increases with silica fume content which adversely affects the mechanical properties, especially at a high content (above $8.0 \mathrm{Wt}$., \%). In order to improve the physico-mechanical properties of OPC-silica fume pozzolanic cement, superplasticizer must be added. The free lime content of blended cement pastes decreases with curing time and silica fume contents. Useful conclusions and recommendations concerning the use of silica fume with $O P C$ in the production of blended cements were obtained.

KEY WORDS: Silica fume (SF), Ordinary Portland cement (OPC), Hydration behavior, Physico mechanical properties.

\section{INTRODUCTION}

A material is said to be pozzolanic if it is capable of combining with calcium hydroxide liberated on hydration Portland cement to form calcium silicates at room temperature The definition implies that a pozzolanic materials contains a reactive silica which combine with liberated lime at significant rates relative to the rate of hydration of cement. ${ }^{(1)}$ The use of pozzolanic cement is increasing worldwide because it needs less energy and low cost for production. The artificial pozzolanic cement is made by intergrinding Portland cement with a portion of pozzolanic material as silica fume, fly ash and slag. ${ }^{(2)}$ Silica fume is a by-product in the production of silicon or its alloys. It is very fine material and has a surface area $\approx 20 \mathrm{~m}^{2} / \mathrm{gm}$. It is a siliceous material and contains (85-95) \% $\mathrm{SiO}_{2}$ in an amorphous state. It reacts with lime in the presence of moisture at normal temperature to form calcium silicate hydrate $\left(\mathrm{CSH}^{)(3)}\right.$

Superplasticizers have been found beneficial in offsetting some of the undesirable characteristics of concrete used especially in hot climate. The advantages of these 
chemical admixtures are: lowering mixing water, retarding the initial and final setting, enhancing the strength and decreasing the drying shrinkage or the permeability ${ }^{(4)}$ The aims of the present study include the following:

1. The effect of addition of different amounts of silica fumes on the properties of ordinary Portland cement pastes and mortars. The hydration behavior was followed by measuring the free lime, evaporable water. Also, the physico-mechanical properties of each mix were measured such as water of consistency, setting times compressive and splitting strengths.

2. The effect of adding super-plasticiser was studied to the last mixes to show its effect on the hydration characteristics and physico-mechanical properties of the hardened cement pastes and mortars up to 90 days.

\section{EXPERIMENTAL TECHNIQUES}

The materials used in this investigation were silica fume from Ferrosilicon Alloys Company (Edfo-Komombo), Aswan, Egypt and ordinary Portland cement provided from Beni Suef Cement Company. The surface area of OPC and silica fume was 3500 $\mathrm{cm}^{2} / \mathrm{g}$ and $20 \mathrm{~m}^{2} / \mathrm{g}$, respectively. The chemical composition of OPC and silica fume is listed in Table 1 . The dry mixes were prepared as shown in Table 2.

Table (1): Chemical composition of the starting material, $\mathrm{W}_{\mathrm{t}} \%$

\begin{tabular}{|c|c|c|}
\hline Oxides & OPC & S.F \\
\hline $\mathrm{SiO}_{2}$ & 21.16 & 95 \\
\hline $\mathrm{Al}_{2} \mathrm{O}_{3}$ & 5.50 & 0.6 \\
\hline $\mathrm{Fe}_{2} \mathrm{O}_{3}$ & 3.21 & 0.8 \\
\hline $\mathrm{CaO}$ & 63.4 & 0.2 \\
\hline $\mathrm{MgO}$ & 69.0 & 0.5 \\
\hline $\mathrm{SO}_{3}$ & 2.40 & 0.1 \\
\hline $\mathrm{Na}_{2} \mathrm{O}$ & 0.5 & 0.2 \\
\hline $\mathrm{K}_{2} \mathrm{O}$ & 0.1 & 0.3 \\
\hline $\mathrm{F} . \mathrm{L}$ & 2.7 & 0.45 \\
\hline $\mathrm{I} . \mathrm{L}$ & 2.3 & 1.2 \\
\hline
\end{tabular}

The superplasticizer was Sikament-RG obtained from Sica Egypt for chemical building material and having the following properties (as indicated by the suppliers):

Nature : liquid

Color : colorless

Density: $1.19 \mathrm{~kg} / \mathrm{litter}$

Each dry mix was homogenized in a porcelain ball mill with two balls for one hour using a mechanical roller to assure complete homogeneity. The water of consistency and setting times for each mix were determined according to ASTM specifications. ${ }^{(5),(6)}$ The compressive and splitting strengths were measured on cement mortars. The mortars were prepared by mixing one part of cement and 2.75 parts of sand proportion by weighing with the water content which sufficient to obtain a flow of $110 \pm 5$ with 25 drops of the flow table. $50 \mathrm{~mm}$ cubes and $50 \times 150 \mathrm{~mm}$ cylinder are 
for compression and splitting tests respectively. ${ }^{(7)}$ Cubes and cylinders are cured in a humidity chamber at $23 \pm 1{ }^{\circ} \mathrm{C}$ for 24 hours, then demolded and immersed in tap water until tested. The test results are the averages of three specimens from a single batch of mortar and tested at the same curing time. Two series of cement pastes and mortars were treated with and without superplasticiser.

Table (2) : Mix composition of the investigated mixes

\begin{tabular}{|c|c|c|c|}
\hline Mix No. & OPC & SF & Superplasticizer \\
\hline $\mathrm{M}_{1}$ & 100 & 0 & - \\
\hline $\mathrm{M}_{2}$ & 96 & 4 & - \\
\hline $\mathrm{M}_{3}$ & 92 & 8 & - \\
\hline $\mathrm{M}_{4}$ & 88 & 12 & - \\
\hline $\mathrm{M}_{5}$ & 84 & 16 & - \\
\hline $\mathrm{M}_{6}$ & 80 & 20 & 0.5 \\
\hline $\mathrm{M}_{7}$ & 100 & 0 & 0.5 \\
\hline $\mathrm{M}_{8}$ & 96 & 4 & 0.5 \\
\hline $\mathrm{M}_{9}$ & 92 & 8 & 0.5 \\
\hline $\mathrm{M}_{10}$ & 88 & 12 & 0.5 \\
\hline $\mathrm{M}_{11}$ & 84 & 16 & 0.5 \\
\hline $\mathrm{M}_{12}$ & 80 & 20 & 1.5 \\
\hline $\mathrm{M}_{13}$ & 100 & 0 & 1.5 \\
\hline $\mathrm{M}_{14}$ & 96 & 4 & 1.5 \\
\hline $\mathrm{M}_{15}$ & 92 & 8 & 1.5 \\
\hline $\mathrm{M}_{16}$ & 88 & 12 & 1.5 \\
\hline $\mathrm{M}_{17}$ & 84 & 16 & 1.5 \\
\hline $\mathrm{M}_{18}$ & 80 & 20 & \\
\hline
\end{tabular}

Hydration behavior of each mix was followed by the determination of free lime as well as evaporable and chemically combined water contents at each time of testing. The free lime content was determined by alcoholic ammonium acetate method. ${ }^{(8)}$ The combined water content $(\mathrm{Wn} \%$ ) was estimated by the ignition of the dried mix at $1000{ }^{\circ} \mathrm{C}$ for 2 hrs. and the combined water content of the hardened mix was corrected. The total water is determined from the ignition of saturated sample, Wt.

Combined water content $=$ ignition loss of the hydrated sample - (ignition loss of the mix + water of free lime).

The evaporable water content of the hardened paste was obtained as:

$\mathrm{We} \%=(\mathrm{Wt}-\mathrm{Wn})$

The total porosity is calculated as: ${ }^{(9)}$

$\zeta=0.99 \mathrm{~W}_{\mathrm{e}} \mathrm{d}_{\mathrm{p}} /(1+\mathrm{Wt}$. $)$

where: dp : the bulk density of the paste in $\mathrm{gm} / \mathrm{cm}^{3}$. 


\section{RESULTS AND DISCUSSION}

\subsection{Hydration Characteristics in Tap -Water Without Superplasticizer}

This part deals with the effect of silica fume content on the hydration behavior as well as phsico-mechanical properties of OPC in tap water without superplasticizer.

\subsubsection{Water of Consistency and Setting Times}

The water of consistency and setting times are graphically represented as a function of silica fume substitution as shown in Fig. 1. It is clear that, the water of consistency tends to increase with the substitution of Portland cement with silica fume. This is due to that, the relatively high surface area of silica fume compared with that of Portland cement. The setting times are elongated with silica fume content, due to the increase of the water of consistency.

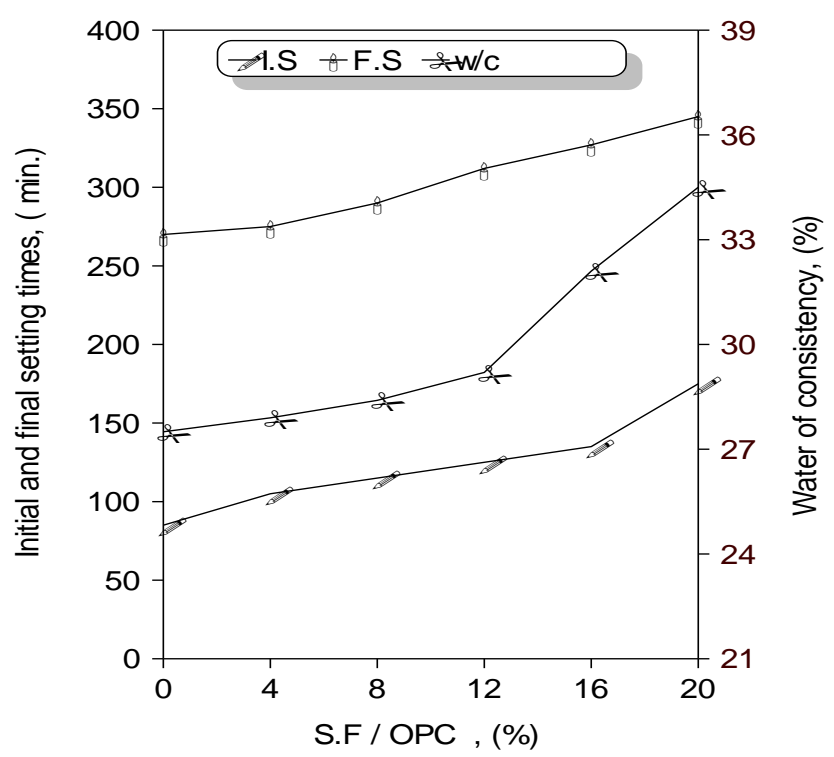

Fig. (1) : Water of consistency and setting times of different blended cement pastes containing OPC with various proportions of S.F .

\subsubsection{Free Lime}

The results of free lime of OPC and blended cement pastes cured up to 90 days are plotted as a function of curing time in Fig. 2. The free lime contents_increase with curing time for OPC cement paste. This is attributed to the continuous hydration of the main cement phases such as $\beta-\mathrm{C}_{2} \mathrm{~S}$ and $\mathrm{C}_{3} \mathrm{~S}$ liberating free lime. On the other hand for blended cement containing silica fume the free lime contents decrease with the silica fume content in the blends. This is due to the reaction of silica fume with liberated lime containing $\mathrm{CSH}{ }^{(10)}$ 


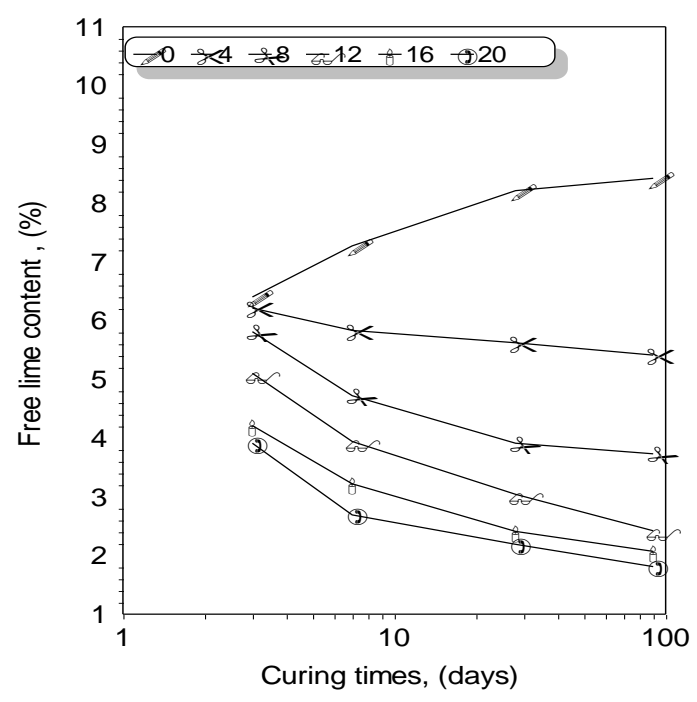

Fig. (2): Free lime contents of different blended cement pastes containing OPC with various proportions of SF immersed in tap water up to 90 day.

\subsubsection{Total Porosity}

The values of total porosity of the hydrated cement pastes are plotted as a function of curing time in Fig. 3. The total porosity of all hardened cement pastes decreases with curing time. This is mainly due the continuous hydration of cement clinker and accumulation of hydration products. These products fill up the open pores, thus increasing the bulk density and decreasing the total pore volume. At a given time of hydration as the replacement of silica fume increases up to $8 \%$ the total porosity increases. This is directly connected with the initial w/c ratio, which plays an important role in the values of total porosity.

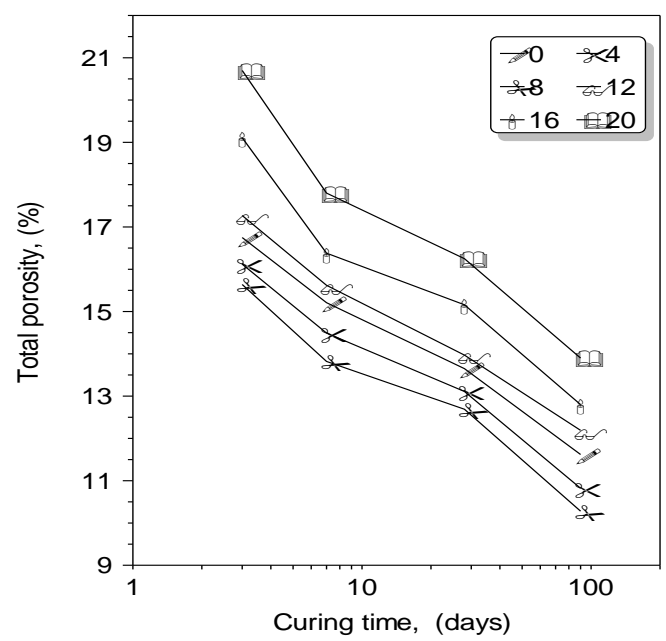

Fig. (3): Total porosity of different blended cement pastes containing OPC with various proportions of SF immersed in tap water up to 90 day. 


\subsubsection{Compressive and Splitting Strengths}

The compressive and splitting strengths of the hardened OPC mortars with and without silica fume are graphically shown in Figs. 4 and 5. It is clear that, the compressive and splitting strengths for all cement mortars increase with curing time. This is due to the increase of the hydration products such as calcium silicate hydrates and more cementing materials are formed and accumulated in water filled pores to give a more compact body. It is clear that the addition of silica fume up to $8 \%$ improves the compressive and splitting strengths. As the substitution of OPC with silica fume increases up to $8 \%$ the strengths decrease. This may be due to that, the mixing water increases with the increase of the silica fume and the free water as well as the total porosity is increased.

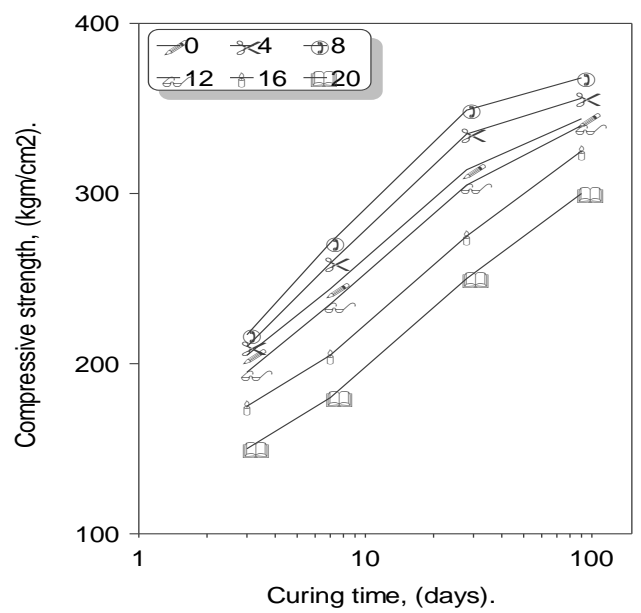

Fig. (4): Compressive strength of different blended cement mortars containing OPC and various proportions of SF with curing time up to 90 days.

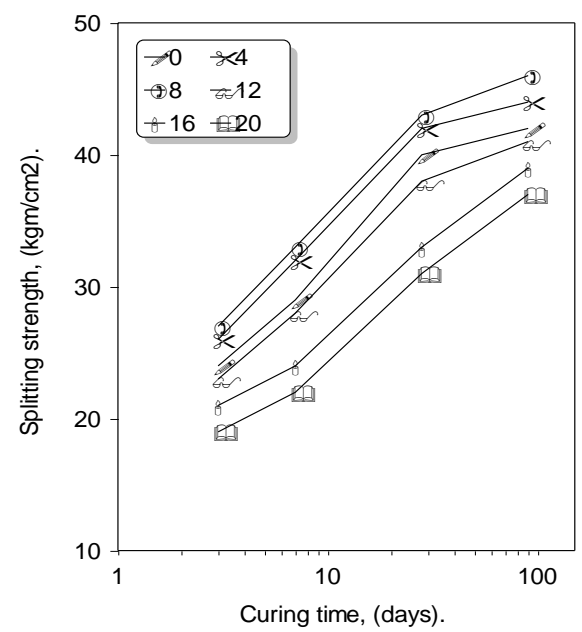

Fig. (5): Splitting strength of mortars containing OPC and different percentages of SF with curing time up to 90 days. 


\subsection{Hydration Characteristics in Tap-Water with adding Superplasticizer}

This part deals with the effect of silica fume content and superplasticizer on the hydration behavior as well as phsico-mechanical properties of OPC in tap water with adding superplasticizer.

\subsubsection{Water of Consistency and Setting Times}

The water of consistency and setting times are graphically represented as a function of silica fume substitution and different dosages of superplasticizer $(0.5,1.5 \%$ by weight of cement) as in Fig. 6. It is clear that the water of consistency decreases with the superplasticizer content. This may be due to the formation of superplasticized thin film around cement grains or/and early formed hydration products, which adversely affects the hydration process and modifies the microstructure of the hydrated. The setting times are elongated as the dosages of admixture increased so that, inhibit the rate of reaction and hence the setting time becomes longer. ${ }^{(11)}$

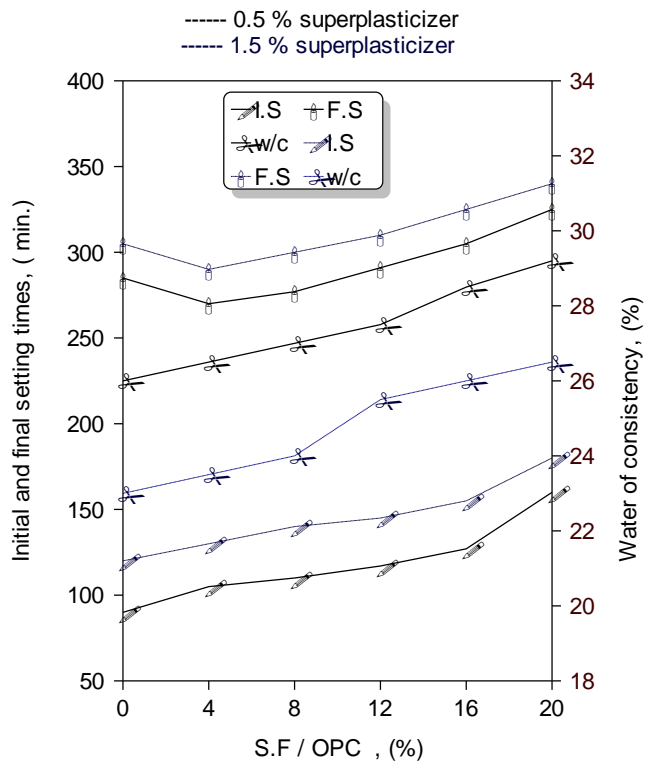

Fig. (6): Water of consistency and setting times of OPC and different percentages of

S.F in the presence of $0.5,1.5 \%$ superplasticizer

\subsubsection{Free Lime}

The results of free lime of OPC and blended cement pastes cured up to 90 days are plotted as a function of curing time in Fig. 7 with the addition of $0.5,1.5 \%$ of superplasticizer. The free lime of OPC increases with curing times as well as admixture percent. This is attributed to the continuous hydration of the main cement phases such as $\beta-\mathrm{C}_{2} \mathrm{~S}$ and $\mathrm{C}_{3} \mathrm{~S}$ liberating free lime. Also the increase of $\mathrm{Ca}(\mathrm{OH})_{2}$ with the amount 
of admixture may be due to the acceleration effect of this water reducer. In the blended cements the liberated lime reacts with silica fume and accordingly the amount of free lime decreases with silica fume contents and dosages of admixture. This may be due to reduction of mixing water that affects the hydration of cement paste and the pozzolanic activity of silica fume. ${ }^{(12)}$

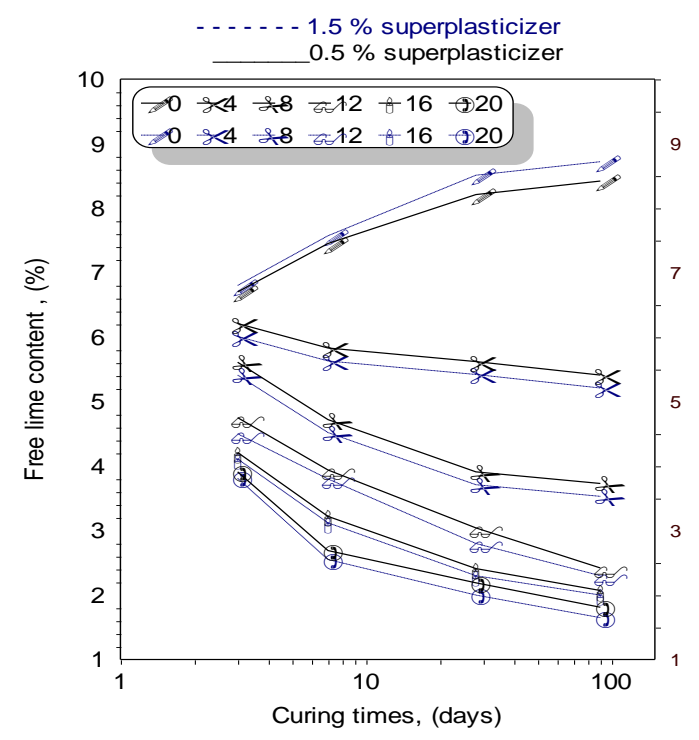

Fig. (7): Free lime contents of cement pastes containing OPC and different percentages of S.F with $0.5,1.5 \%$ superplasticizer cured up to 90 days.

\subsubsection{Total Porosity}

The values of total porosity of the hydrated cement pastes in the presence of 0.5 and $1.5 \%$ of superplasticizer are plotted as a function of curing time in Fig. 8. The total porosity of the all hardened cement pastes decreases with curing time. As the dosages of admixtures increases the total porosity decrease. The superplasticizer improves dispersion of cement and silica fume particles. The mechanism may be related to interparticular tension generated by the dispersing, which helps keep silica fume particles separated until the dissolution process begins. Gradual dissolution of silica fume into a gel in the matrix and its reaction with lime to form CSH occur. This is strongly reflected in the total porosity of very high strength concrete undergoing progress hydration.

\subsubsection{Compressive and Splitting Strengths}

The compressive and splitting strengths of the hardened OPC and blended cement mortars in the presence of 0.5 and $1.5 \%$ of superplasticizer are graphically shown in Figs. 9 and 10. It is clear that, the compressive and splitting strengths for all cement mortars increases with curing time due to the increase of the hydration products such as calcium silicate and aluminosilicate hydrates. As the dosages of admixture increases the strengths increase. This is due to the reduction of mixing water that affects the total 
porosity. It is clear that the compressive and splitting strengths enhance with curing time as well as the amount of silica fume added up to $20 \%$ and in the presence of superplasticizer. This is due to the pozzolanic activity of silica fume and superplasticizer which decreases the water of consistency and consequently the total porosity and leading to the improvement of the degree of compaction.

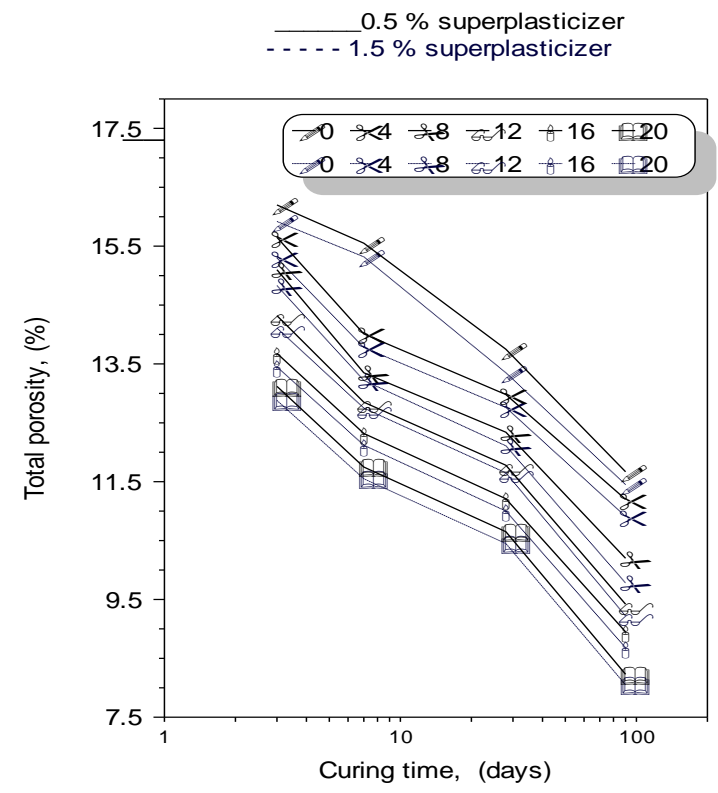

Fig. (8): Total porosity of cement pastes containing OPC and different percentages of S.F with $0.5,1.5 \%$ superplasticizer cured up to 90 days.

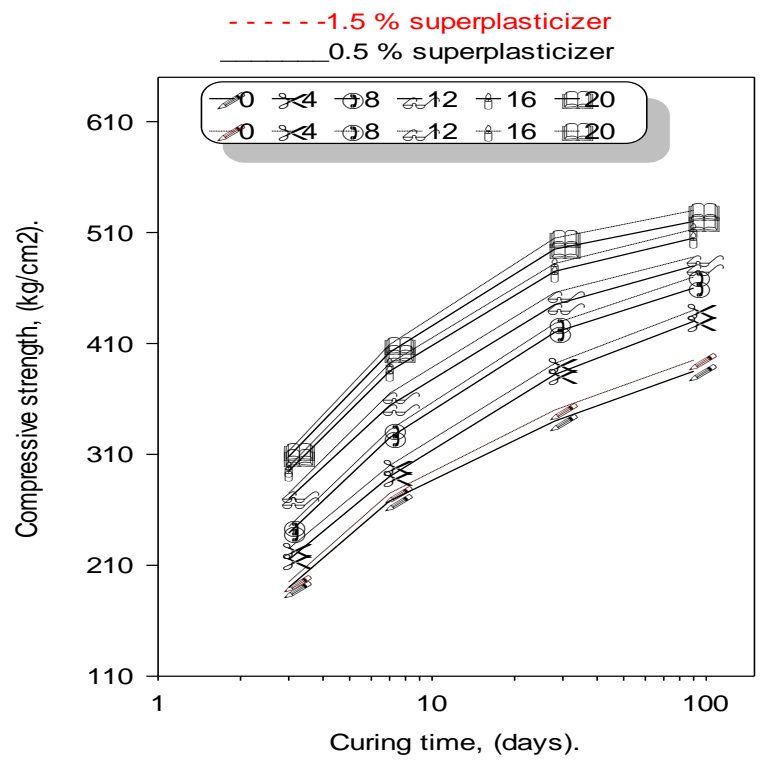

Fig. (9): Compressive strength of mortars containing OPC and different percentages of S.F with $0.5,1.5 \%$ superplasticizer cured up to 90 days 


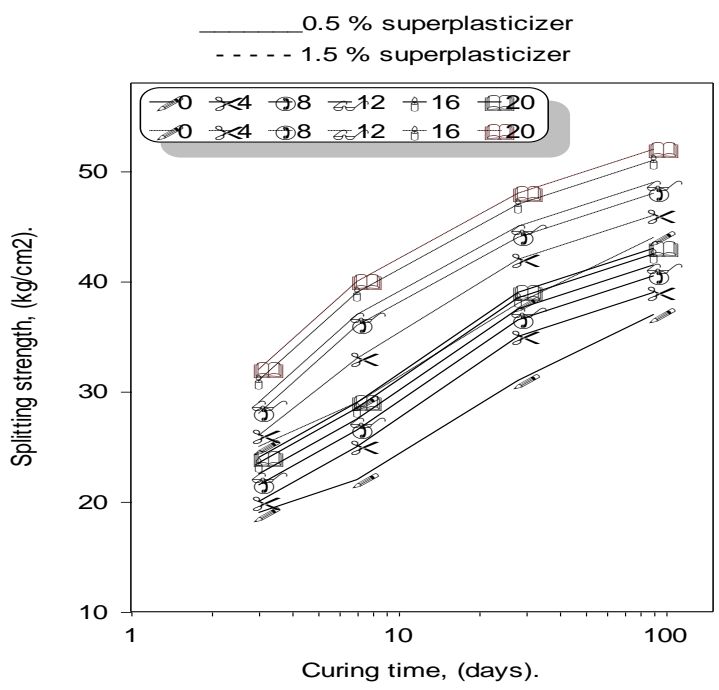

Fig. (10): Splitting strength of mortars containing OPC and different percentages of SF with $0.5,1.5 \%$ superplasticizer cured up to 90 days.

\section{CONCLUSION}

The present work concerns the effect of silica fume substitution on the characteristics of ordinary Portland cement pastes and mortars. Different mixes of OPC with various proportions of silica fume with and without super-plasticiser were prepared and hydrated up to 90 days. The following conclusions can be recorded and summarized as following:

1- The water of consistency tends to increase with the substitution of Portland cement with silica fume and the setting times are elongated

2- The free lime decreased with the substitution of Portland cement with silica fume but the porosity increased up to $8 \%$ and consequently the compressive strength decreased

3- Adding superplasticizer reduced water of consistency and elongated the time of setting

4- The free lime and the total porosity decreased with increasing dosages of the superplasticizer

5- The compressive and splitting strengths enhanced and the results show high strengths at later ages. This is due to the pozzolanic activity of silica fume and reducing the amount of mixing water.

6- From obvious results it can be concluded that adding superplasticizer is very important in the case of blended cement (OPC + silica fume).

\section{REFERENCES}

1. Mehta P.K., Gjorv O.E, Properties of Portland Cement Concrete Containing Fly ash and Silica fume "Cement Concrete Research 12,587-595 (1982). 
2. Malhotra V.M., Ramachandran V.S , Feldman R.F., and Aiticn P.C. “ Condensed Silica Fume in Concrete “ PP 1-5, CRC Press Inc., Baca Raton Florida , (1987).

3. Malhotra V.M., Ramachandran V.S , Feldman R.F., and Aiticn P.C. " Condensed Silica Fume in Concrete “ PP 1-5, CRC Press Inc., Baca Raton Florida, (1987).

4. Ramachandran V.S. "Concrete Admixture, Hand Book "PP.54-115,NP Nayes Publications, Park Ridge, New Jersey 1984.

5. ASTM Standards, Standard Test Method for Normal Consistency of Hydraulic Cement, ASTM C187- 83, 195,(1983).

6. ASTM Standards, Standard Test Method for Setting of Hydraulic Cement by Vicat Needle ASTM C191-82, 208,(1983) .

7. ASTM Standards, Standard Test Method for Compressive Strength of Hydraulic Cement Mortars, ASTM Designation, C109-92, 62,(1992)

8. El-Didamony, H.; Haggag,M.Y. and Abo- El-Enein, S.A, Cem.Concr. Res., 8351, (1978).

9. Kondo, R., Abo EL-Enein, S.A. and Diamon , M. Bull. Chem, Soc, Jpn. ,48, 22 (1975).

10. Lea, F.M.," The Chemistry of Cement and Concrete" , 3rd. Edn., Edward LTD (1976).

11. El-Didamony, H.; Helmy I.M., Amer A.A., Heikal M. “ Zement Kalk - Gips “ 9,502 (1995)

12. Tkalces, E., and Zelic ,J. “ Influence of amorphous silica dust on the properties of portland cement mortars, Zement Kalk - Gips “ 40 (1995) No 11 , pp 574-579 .

13. ACI Committee 305, Hot Weather Concrete, ACI Mater. J., 88(4) 417-436 (1991).

\section{تأثير الملانات على الاسمنت البوزولانى المختلط بتراب السيليكا}

فى هذا البحث تم دراسـة مدى الاستفادة من تراب السليكا المنتج مـن مصـانع الفيروسيليكون بأسـوان

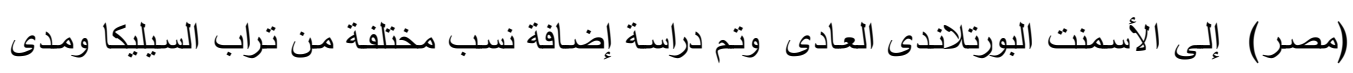
تأثثرها على الخواص الكيميائية والفيزيقو - ميكانيكية للأسمنت وتم التوصل إلى انه عند إضـافة تراب السيلكا الى الأسمنت العادى فانه يؤدى إلى تحسين بعض الخواص ولكنه يحتاج الى زيادة ماء الخلط مما يؤثر على الخواص الميكانيكية لذلك تم دراسـة استخدام إضـافة تقليل ماء الخلط بنسب مختلفة على الخواص الكيميائية والفيزيقو ميكانيكية لاسمنت. 